Biol. Neonate 1976;29:I-V

\title{
Contents, Vol. 29, 1976
}

\section{Contents}

No. 1-2

Salle, B. and Ruitton-Uglienco, A.: Glucose Disappearance Rate, Insulin Response and Growth Hormone Response in the Small for Gestational Age and Premature In fant of Very Low Birth Weight 1

Stoddart, R.W. and Widdowson, E.M.: Changes in the Organs of Pigs in Response to Feeding for the First $24 \mathrm{~h}$ after Birth. III. Fluorescence Histochemistry of the Carbohydrates of the Intestine 18

Velazquez, A.; Rosado, A.; Bernal, A.; Noriega, L·, and Arévalo, N,: Amino Acid Pools in the Feto-Maternal System 28

Palkovic, M.;Macho, L.; Skottova, N., and Hostacka, A.: Influence of Early Weaning on the Activity of Several Enzymes in the Liver of Rat 41

Robinson, B.H.: Development of Gluconeogenic Enzymes in the Newborn Guinea Pig . 48

Cooper, A.J. and Cowley, J.J.: The Effect of Litter Size on the Growth, Survival and Behaviour of Neonatal Bulbectomised Mice 56

Zarif, M.A.; Pildes, R.S.; Szanto, P.B., and Vidyasagar, D.: Cholestasis Associated with Administration of L-Amino Acids and Dextrose Solutions 66

Adebonojo, F.O.: Triglyceride Mobilization in Cultured Adipocytes of Human Infants. 77

Schettini, F.; Mattia, D. de; Mautone, A., and Altomare, M.: Post-Natal Development of Factor II (Pre-Prothrombin and Prothrombin) in Man 82

Abdul-Karim, R.W.; Pavy, M.; Beydoun, S.N., and Haviland, M.E.: The Regulatory Effect of Estrogens on Fetal Growth. IV. Brain Development in Growth Acceler ated Fetuses in Rabbits 89

Kolena, J.: Ontogenic Development of the Responsiveness in cAMP Synthesis to LH and PGE, and Gonadotropin Receptors in the Rat Ovary 96

Mersmann, H.J.; Phinney, G., and Brown, L.J.: Factors Influencing the Lipolytic Re sponse of Swine (Sus domesticus) Adipose Tissue: Ontogeny 104

Rubaltelli, F.F.; Rondinelli, M.; Zorzi, C, and Saia, O.S.: Amniotic Fluid Surface

Tension during Pregnancy 112

Dlouhá, H.: A Micropuncture Study of the Development of Renal Function in the

Young Rat 117

Contents

IV

No. 3-4

McLennan, J.E.: Rib Anomalies in Myelodysplasia. An Approach to Embryologic In ference 129

Torda, C: Effects of Recurrent Postnatal Stresses on Hypothalamic Concentrations of Norepinephrine 142

Krukowski, M. and Smith, J.J.: pH and the Level of Calcium in the Blood of Fetal and 
Neonatal Albino Rats 148

Jonsson, C.-E.; Tuvemo, T., and Hamberg, M.: Prostaglandin Biosynthesis in the $\mathrm{Hu}$ man Umbilical Cord 162

Luke, D.A.: Dental and Craniofacial Development in the Normal and Growth-Retarded Human Fetus 171

Sounders, R.A.; Milner, A.D., and Hopkin, I.E.: The Effects of Continuous Positive Airway Pressure on Lung Mechanics and Lung Volumes in the Neonate 178 $\mathrm{Tu}, \mathrm{J}$. and Wong, C: Serotonin Metabolism in Normal and Abnormal Infants during the Perinatal Period 187

Dambska, M.; Dydyk, L.; Szretter, 71; Wozniewicz, J., and Myers, R.E.: Topography of Lesions in Newborn and Infant Brains following Cardiac Arrest and Resuscitation.

Damage to Brain Stem and Hemispheres 194

Teng, E.L.; Harel, S.; Hartzler, J.; Shapira, Y.; Quilligan, E., and Meulen, J.P. van der: Relations between Birth Weight and Learning Ability in Young Rabbits 207 Amortegui, A.J.; Feinberg, St.S., and Figallo, E.M.: Postnatal Effects of Chemically Induced Intrauterine Growth Retardation on Some Hematological Values in the Rat 216

Cloonan, M.J. and Shortland, G.M.: Postnatal Decline of Maternally Acquired Anti bodies in the Rat 222

Harris, H.; Wilson, S.; Brans, Y.; Wirschafter, D., and Cassady, G: Nasal Continuous Positive Airway Pressure. Improvement in Arterial Oxygenation in Hyaline Mem brane Disease 231

Farrell, Ph.M.; Epstein, M.F.; Fleischman, A.R.; Oakes, G.K., and Chez, R.A.: Lung Lecithin Biosynthesis in the Nonhuman Primate Fetus: Determination of the Primary Pathway in vivo 238 Ogata, E.S. and Holliday, M.A.: The Effects of Starvation, Glucose Infusion, and Normal Feeding, on Muscle Protein Synthesis and Catabolism in the Newborn Guinea Pig 247

No. 5-6

Solomon, S.; Bengele, H.H., and Evan, A.P.: Amino Acid Uptake by Fetal Kidney Slices 257

Girard, J.R.; Chanez, C.| Kervran, A.; Tordet-Caridroit, C, and Assan, R.: Studies on Experimental Hypotrophy in the Rat. III. Plasma Insulin and Glucagon 262 Petersen, K.W.; Jacobson, C.B.; Telford, I.R., and Del Var Petersen, H.: A Survey of X Chromatin in the Newborn 267

Palkovic, M.; Skottová, N., and Hostacká, A.: Blood Lipids during Normal and Early Meaning in Rats 274

Mühlendahl, K.E. von; Pachaly, J., and Schmidt-Gollwitzer, M.: Lack of Correlation between Clinical Data and Growth Hormone Concentrations in Cord Blood . . . 281 Contents

$\mathrm{V}$

Jones, C.T. and Ritchie, J.W.K.: Endocrine and Metabolic Changes Associated with Periods of Spontaneous Hypoxia in Fetal Sheep 286

Constantopoulos, A.; Xypolita, A., and Matsaniotis, N.: Adenylate Cyclase Activity in Human Tissues 294

Fenton, E.; Button, H.G., and Nixon, D.A. $\uparrow$ : A Study of the Permeability of the 
Guinea Pig Placenta to Citrate Using Recirculating Placental Perfusion Technique . 299 Kaskel, F.J. and Kleinman, L.I.: Effect of Diet on Renal Response to Salt Challenge in Neonatal Piglets 306

Egberts, /.; Fontijne, P., and Wamsteker, K.: Indication of Increase of the Lecithin/ Sphingomyelin (L/S) Ratio in Lung Fluid of Lambs Maternally Treated with Metabolite VIII of Bisolvon ${ }^{\circledR}$ 315

Hervei, S.; Malik, T., and Rötfalusy, M.: Acid-Base Changes of Mature and Premature Neonates following Exchange Transfusion 323

Yao, A.C.; Nergårdh, A., and Boréus, L.O.: Influence of Oxytocin and Meperidine on the Isolated Human Umbilical Artery 333

Schwieler, G.H. and Robertson, B.: Liquid Ventilation in Immature Newborn Rabbits . 343

Eshet, R.; Assa, S., and Laron, Z.: Heterogeneity of Pituitary and Endogenous Plasma Human Growth Hormone from Fetuses, Premature and Full-Term Newborns . . 354 Hoff, K.M.; Baker, P.C., and Buda, R.E.: Precursor and End Product Effects upon Indoleamine Maturation in Mouse Brain 360

Legrand, /.; Selme-Matrat, M.|' Rabié, A.; Clos, J., and Legrand, C: Thyroid Hormone and Cell Formation in the Developing Rat Cerebellum 368 Varia 381

Author Index 382

Subject Index 384 